\title{
TANTANGAN INDEPENDENSI MEDIA DALAM PEMILU: KASUS KOMPAS.COM
}

\author{
Nurul Khotimah \\ Fakultas Dakwah dan Komunikasi UIN Walisongo Semarang \\ Email: nurulkhotimah134@gmail.com
}

\begin{abstract}
7 he aim of this study is to describe media ideology and construct media independence in the 2019 political year. Ideology has a major influence on the determination of media content. It is as if the general election democracy party cannot be separated from the mass media, so that the reporting of events "attacking each other" by the candidate pair cannot be avoided in the general election contestation. The object of the study was Kompas.com reporting on time limitations during the 2019 presidential and vice presidential election campaign. The research method used was qualitative library research. Data collection techniques using documentation. The results showed that the challenge of media ideology in maintaining the independence of media coverage in the political year must use the principles of independence. They are the presence or absence of opinion, personalization, sensation, stereotype, linkage, and accuracy in reporting.
\end{abstract}

Keywords: Ideology, Independence of the Media, KOMPAS.COM, General Election News

\begin{abstract}
ABSTRAK
$\mathrm{P}$ enelitian ini bertujuan untuk mendiskripsikan ideologi media dan mengonstruksi independensi media di tahun politik 2019. Ideologi memiliki pengaruh besar terhadap penentuan konten media. Pesta demokrasi pemilihan umum seakan tidak bisa lepas dari media massa. Pemberitaan kejadian "saling-serang" masing-masing kubu pasangan calon tidak bisa dihindari dalam kontestasi pemilihan umum. Objek yang diteliti adalah kasus pemberitaan pemilu di KOMPAS.COM dengan limitasi waktu pada masa kampanye pemilihan presiden dan wakil presiden 2019. Metode penelitian yang digunakan adalah library research kualitatif. Teknik pengumpulan data menggunakan teknik dokumentasi. Hasil penelitian menunjukkan bahwa tantangan mempertahankan ideologi media dalam menjaga independensi pemberitaan pemilu di tahun politik harus menggunakan prinsip independensi yaitu ada tidaknya opini, unsur personalisasi, sensasi, stereotype, linkage, dan akurasi dalam pemberitaan.
\end{abstract}

\section{Kata Kunci: Ideologi, Independensi Media, KOMPAS.COM, Berita Pemilu}


Tantangan Ideologi Dan Independensi ...hal 133-145

\section{PENDAHULUAN}

Kata ideologi dewasa ini sering digunakan dalam berbagai praktek kehidupan. Indonesia menganut ideologi pancasila. Pemilikan ideologi selain ditujukan pada Negara, kelompok, organisasi dan individu, juga sebagai landasan dan orientasi nilai yang dianut dalam praktek kehidupan sehari-hari. Ideologi bisa merupakan nilai yang ditetapkan dan dipaksakan oleh suatu kekuatan atau juga murni merupakan refleksi dari nilai-nilai yang dianut individu, kelompok, golongan atau kelas tertentu (Rusadi, 2015: 52).

Lingkup kajian media mencakup penggunaan media khususnya media massa dan media baru berbasis internet. Penggunaan disini bisa dalam pengertian masyarakat yang memanfaatkan media atau pihak yang menggunakan lembaga media untuk kepentingan ideologi tertentu. Sebagai sebuah lembaga dalam masyarakat, media memiliki landasan ideologis yang membingkai isinya agar sejalan dengan ideologi media. Namun demikian, sebagai wahana yang menyalurkan isi media dari berbagai sumber, kemungkinan mereka memanfaatkan untuk menunjukkan eksistensi ideologisnya atau untuk memperjuangkan dan mempertahankan ideologi diantara berbagai ideologi yang ada.

Media massa ada yang berdiri secara independen, ada yang ditunggangi kepentingan politik oleh beberapa golongan. Bahkan ada juga media massa yang bisa ditunggangi atau disetir pemerintah. Media massa sebagai jembatan informasi kepada masyarakat, seharusnya menampilkan informasi sejelas-jelasnya dan tidak hanya dari satu sudut pandang. Media massa memegang peranan krusial dalam kestabilan sosial.

Secara teori normative pemberitaan di media massa harus netral dengan bersikap independen berdasarkan kebijakan ideologi masing-masing media massa. Namun faktanya, media seringkali dipengaruhi oleh kepentingan politik kekuasaan baik perseorangan maupun kelompok, dan media sebagai industri komersial guna mempertahankan eksistensi media massa tersebut. Sehingga publik dalam arti masyarakat seringkali memandang sebelah mata terhadap berita yang disajikan, khususnya di tahun politik.

Sementara, dari hasil penelitian pada Pilpres 2014 mencatat, media konvensional maupun online pada kurun 1-7 November 2013 menunjukkan kepemilikan media massa oleh satu pengurus partai politik yang ikut bertarung, ada kecenderungan mendukung kegiatan partai politik yang diusung pemiliknya. Menjawab perihal ideologi media dalam hal ini independensi media pada Pilpres 2019 tentu menjadi menarik untuk dibahas. Permasalahan independensi media biasanya merujuk pada berita walau sebenarnya juga berpengaruh pada isi hiburan dan iklan. Namun, penerapan independensi lebih ketat diwujudkan dalam isi berita.

Perhatian publik yang mempersoalkan independensi media dalam kontes pemilihan umum di Indonesia dijadikan rujukan dari pembahasan ini.

\section{METODE PENELITIAN}

Pada penelitian ini menggunakan kajian library research kualitatif. Penelitian kualitatif merupakan metode-metode untuk mengeksplorasi dan memahami makna yang oleh sejumlah individu atau sekelompok orang dianggap berasal dari masalah sosial atau kemanusiaan (Creswell, 2010: 4). Tipe 
penelitian yang digunakan adalah tipe interpretatif, sehingga bias, nilai dan prasangka peneliti dinyatakan secara implicit dalam laporan penelitian (Bungin, 2006: 78).

Sumber data dalam penelitian ini adalah pemberitaan media massa di Kompas.com dengan limitasi waktu dari 24 Maret 2019 hingga 13 April 2019. Karena dari kurun waktu tersebut telah dijadwalkan iklan pasangan capres-cawapres Pilpres 2019 di media massa oleh Komisi Pemilihan Umum (KPU) yang diatur dalam Peraturan KPU (PKPU) Nomor 23 tahun 2018 tentang Kampanye.

Teknik pengumpulan data dalam penelitian ini yaitu dokumentasi. Mendokumentasikan berita dari Kompas.com yang berkaitan dengan kampanye pasangan capres-cawapres pemilu 2019 dengan cara menggunakan kata kunci 'kampanye' pada menu icon pencarian, menyimpan link url dan screenshot.

\section{KERANGKA TEORI}

\section{Konsep Ideologi Media}

Ideologi adalah kumpulan beberapa ide dan gagasan. Kata ideologi diciptakan oleh Destutt de Tracy pada akhir abad ke-18 untuk mendefinisikan sains tentang ide (Jary, 1991:71). Secara umum, ideologi merupakan ide atau gagasan bagi seseorang atau kelompok yang menjadi pegangan atau prinsip dalam menjalani kehidupannya. Ideologi dengan demikian beroperasi dalam pikiran, perasaan yang diekspresikan dalam ucapan, tulisan, tindakan, perilaku langsung dan output lainnya seperti produk media baik visual atau verbal, atau dalam arsitektur gedung-gedung dan bangunan lainnya, musik, drama dan berbagai bentuk pertunjukan atau performance (Rusadi,

2015: 95).

Menurut Hall (1981) ideologi mengacu pada: those images, concept and premises which provide the framework through which we represent, interprent, understand, and 'make sense' of some aspect of social existence (segala gambaran, konsep dan gagasan menjadi dasar pijakan yang digunakan untuk menyajikan, menginterpretasikan, mengerti dan 'menerima' aspek-aspek keberadaan masyarakat.

Raymond William sebagaimana dikutip Eriyanto mengklasifikasikan penggunaan ideologi dalam tiga area, yakni: Pertama, sebuah sistem kepercayaan yang dimiliki kelompok atau kelas tertentu. Ideologi sebagai seperangkat sikap yang dibentuk dan diorganisasikan dalam bentuk yang koheren.

Kedua, ideologi merupakan sebuah sistem kepercayaan yang dibuat (ide atau kesadaran palsu) yang bisa dilawankan dengan pengetahuan ilmiah. Ideologi dalam pengertian ini adalah seperangkat kategori yang dibuat dan kesadaran palsu di mana kelompok yang berkuasa atau dominan menggunakannya untuk mendominasi kelompok lain yang lemah. Perangkat ideologi yang digunakan kelompok dominan terhadap kelompok lain akan mengakibatkan hubungan yang terjalin tampak natural dan diterima sebagai kebenaran. Di sini, ideologi disebarkan melalui berbagai instrumen yang salah satunya adalah media massa.

Ketiga, ideologi diartikan sebagai proses produksi makna dan ide. Ideologi bekerja merumuskan makna secara eksklusif yang merepresentasikan kepentingan kelompok tertentu yang dominan. Melalui perumusan makna ini, ideologi mengkonstruksi dan memproduksi makna suatu realitas secara sewenang- 
Tantangan Ideologi Dan Independensi ...hal 133-145

wenang untuk kepentingan partisan (Hall, 1981:180).

Ideologi, menurut Fairclough, diproduksi dan direproduksi untuk kepentingan kekuasaan (Fairclough, 1992:87). Eksistensinya sangat krusial untuk mendukung atau melanggengkan relasi kuasa dalam struktur sosial atau dalam masyarakat. Pernyataan ini sejalan dengan definisi ideologi yang diberikan Fairclough sebagai "significations/ constructions of the reality, which are built into several various dimensions of the forms/meanings of discursive practices and which contribute to the production, reproduction or transformation of relations of dominations" (Jorgensen, 2002: 75). Konstruksi makna terhadap realitas melalui bahasa, baik dalam hal pemaknaan tentang dunia, relasi sosial, dan identitas sosial, bersifat ideologis karena berpretensi untuk memapankan relasi dominasi dalam masyarakat.

Dalam konteks media massa, ideologi dibentuk bukan dalam ruang hampa. Berita diproduksi dari ideologi dominan tertentu yang berasal tidak hanya dalam arti ide-ide besar, tetapi juga bisa bermakna politik penandaan dan pemaknaan. Sementara Gramsci mengemukakan bahwa hubungan pemilik modal dan pekerja yang dalam konteks media massa antara wartawan dan pemilik industri media merupakan hubungan yang bersifat hegemonik (Gramsci, 1999: 124). Tujuan utama dibalik ideologi adalah untuk menawarkan perubahan melalui proses pemikiran normatif. Selain ideologi sebagai perangkat internal media, kekuatan lain yang secara massif membentuk kecenderungan kepentingan dan keberpihakkan media adalah sumber berita (news source), pengiklan (advertiser), konsumen berita (news consumers), dan publik (the general public).

\section{Konsep Independensi Media}

Independen dalam arti merdeka melaksanakan ideologi jurnalisme. Independensi adalah salah satu sikap yang mutlak dimiliki oleh setiap lembaga media massa/pers. Independensi merupakan standar kualitatif yang diperlukan oleh suatu kantor akuntan publik untuk bertindak dengan integritas dan obyektifitas dalam melaksanakan tugas profesionalnya.

Independensi mencerminkan sikap tidak memihak serta tidak dibawah pengaruh atau tekanan pihak tertentu dalam mengambil keputusan dan tindakan. Independensi dalam konteks media massa adalah tetap dalam prinsip-prinsip yang sangat jelas, yakni cover all side, bagaimana media massa secara sadar menempatkan publik sebagai sesuatu yang utama. Sehingga dapat disimpulkan bahwa Independensi media berarti bahwa dalam memproduksi isi media tidak ada tekanan dari pihak lain. Independensi didefinisikan sebagai kemerdekaan yang dimiliki oleh ruang redaksi dalam memproduksi berita.

Faktor-faktor yang mengindikasikan independensi; pertama, sikap mental yang bebas dari pengaruh. Publik pada saat masa penugasannya tidak dipengaruhi oleh kepentingan-kepentingan berbagai pihak sehingga menghasilkan sebuah berita yang berkualitas. Kedua, tidak dikendalikan oleh pihak lain. Publik melakukan tugasnya bebas dari kendali pihak luar yang menginginkan sebuah hasil berita yang dikendalikan, sehingga berita yang dihasilkan bebas dari rekayasa apapun. Ketiga, tidak tergantung pada orang lain. Publik pada masa penugasannya tidak bergantung pada pihak lain sehingga membuat berita yang dikeluarkan diragukan kebenarannya (Mulyadi, 2008: 45). 
Suara UU pers adalah suara kemerdekaan pers sebagai bagian dari HAM. Kini independensi media massa sudah mulai luntur karena gesekan-gesekan sosial, ekonomi, maupun kebudayaan. Banyaknya intervensi yang datang pun tidak hanya lewat kekuasaan politik, pejabat atau lembaga negara/pemerintahan, intervensi para penguasa informal serta masyarakat, perintah-perintah pemilik penguasa perusahaan pers, tapi juga intervensi dalam bentuk hadiah (uang), bahkan jabatan yang sangat menggiurkan.

Independensi media yang sudah mulai luntur, sudah selayaknya mendapat perhatian yang serius oleh pemerintahan dalam hal ini KPI (Komisi Penyiaran Indonesia) dan DPI (Dewan Pers Indonesia) harus segera menindak tegas, menegur setiap lembaga yang lalai dalam pemberitaan sebagai lembaga yang menjalankan fungsi pengawasan, UU No. 32 Tahun 2002 tentang penyiaran memberikan KPI kewenangan untuk menampung pengaduan masyarakat dan melakuan pemantauan.

\section{Karakteristik Independensi Berita}

Berita dari segi etimologis berasal dari bahasa Sansekerta, yaitu vrit, vritta (kejadian atau yang telah terjadi) (Yunus, 2012: 45). Dalam bahasa Inggris disebut news. Berasal dari bahasa Latin, novum, nova artinya baru. Dalam Islam term berita disebut al-naba', al-khabar dan al-hadits semuanya berpadanan dengan makna pemberitaan. Pers Timur berbeda sistemnya dengan Pers Barat. Pers Timur tidak memandang berita sebagai komoditi, berita bukan barang dagangan. Berita adalah suatu proses yang ditentukan arahnya (Kusumaningrat, 2005: 32).

Berita merupakan informasi terkini tentang sesuatu yang terjadi di suatu tempat, atau tentang sesuatu hal yang belum diketahui sebelumnya. Berita adalah informasi yang disajikan oleh media pemberitaan seperti Koran, radio, maupun televisi. Berita yaitu segala hal atau sesuatu yang berharga oleh media berita sebagai subjek bernilai dari reportase (Kusumaningrat, 2005: 39).

Produksi berita merupakan proses kolaborasi dimana tim dipersatukan oleh otoritas editor, oleh pemahaman yang sama terhadap nilai-nilai dan oleh suatu pemahaman terhadap peran-peran dalam tim. Proses pembuatan berita merupakan proses yang mengalir dari kontak pertama dengan sumber berita menuju waktu ketika berita tayang di halaman atau layar. Ada tiga tahapan yaitu; pengumpulan dan pemilihan, pengeditan (pemilihan lebih lanjut), dan pengkonstruksian. Proses selektif pengumpulan dan penyuntingan berita secara fundamental ditentukan oleh asumsiasumsi para pembuat berita, tentang pokok persoalan dan perlakuan berita mana yang dianggap berharga dan sebaliknya. Nilai ini dapat diungkapkan menurut kepentingannya bagi masyarakat, tetapi nilai tersebut dapat dilihat sebagai tolak ukur kepentingan ideologis (Burton, 1999: 110).

Suatu peristiwa layak diberitakan atau tidak, dapat dinilai melalui sifat-sifatnya. Cara menilainya dengan menganalisis berita tidak lepas dari unsur consequencies, timeless, proximity, prominence, dan human interest. Consequencies berarti dampak atau akibat. Berita-berita yang disajikan bernilai tinggi apabila fakta atau peristiwa yang dihadirkan di dalamnya mempunyai relevansi dengan kehidupan khalayak. Timeless memiliki arti kebaruan atau aktualitas, artinya suatu peristiwa adalah kejadian yang baru saja terjadi. Nilai berita timeless bisa dimaknai sebagai semua 
Tantangan Ideologi Dan Independensi ...hal 133-145

informasi yang membantu khalayak dalam mengatur kehidupan mereka.

Proximity bermakna sebagai kedekatan. Peristiwa yang terjadi dekat dengan tempat tinggal para pembaca. Semakin dekat suatu kejadian dengan khalayak, maka semakin bernilai tinggi beritanya. Proksimitas atau kedekatan tidak hanya dapat dimaknai secara geografis-fisik saja, namun juga dapat dimaknai secara kultural. Prominence yaitu melibatkan tokoh terkemuka, orang penting atau orang terkenal. Human interest merupakan menarik dari sudut kepentingan kemanusiaan (Lukmantoro, 2014: 4-5).

Ada beberapa kecenderungan berita yang dapat diidentifikasi pada beberapa surat kabar maupun berita online;

Pertama, mengenai materi atau bahan berita. Ada lima materi yang dijadikan bahan berita, yakni berita yang didasarkan atas kejadian atau peristiwa, berita yang ditulis berdasarkan opini orang, berita yang diangkat berdasarkan momentum tertentu, berita yang didasarkan pada suatu isu, dan berita yang mengangkat suatu permasalahan.

Kedua, terkait format penulisan. Beritaberita yang terdapat pada beberapa surat kabar dapat dikategorikan menjadi tiga format penulisan, yakni berita lugas (straight news), berita halus (soft news) dan berita kisah (feature). Ketiga, terdapat dua pendekatan penulisan berita, yakni pendekatan dengan format berita objektif dan pendekatan dengan format berita interpretatif. Berita objektif adalah berita yang sumber dan bahan beritanya didapat hanya dari "lapangan". Sedangkan, berita interpretatif merupakan berita yang sumber dan bahan beritanya didapat dari "lapangan" ditambah dan dilengkapi dengan fakta lain, seperti dokumen, berita lain yang relevan dan perspektif.
Keempat, terdapat kecenderungan media untuk memberitakan peristiwa, isu atau permasalahan yang media lain tidak memberitakannya, yang dijadikan headline news diluar berita mainstream. Media yang "berani" melakukan ini biasanya media mapan dengan "misi" tertentu. Seperti misi kemanusiaan, lingkungan, perlindungan industry kecil, petani dll. Kelima, berita dilengkapi dengan sketsa, untuk memberi gambaran ringkas tentang fenomena yang berkairan dengan kronologi kejadian, tabel dan ringkasan.

\section{Prinsip Independensi Media}

McQuail (1992) menguraikan beberapa indikator penting dalam melihat persoalan independensi (objektivitas), diantaranya: ada tidaknya opini, unsur personalisasi, sensasionalisme, stereotype, juxtaposition atau linkage, dan akurasi dalam pemberitaan. Unsur personalisasi dalam pemberitaan diartikan sebagai pandangan yang melihat pemilik atau aktor politik sebagai aktor utama/penting atau tunggal yang paling berpengaruh dalam sebuah peristiwa.

Sensasionalisme (emosionalisme dan dramatisasi) merupakan dimensi-dimensi yang mengukur netralitas berita. Unsur sensasionalisme dalam berita diartikan sebagai sifat suka menimbulkan sensasi. Dramatisasi diartikan sebagai bentuk penyajian atau penulisan berita yang bersifat hiperbolik dan melebih-lebihkan sebuah fakta dengan maksud menimbulkan efek dramatis bagi pembacanya.

Stereotype dalam konteks pemberitaan berkaitan dengan ada tidaknya pemberian atribut tertentu terhadap individu atau kelompok dalam penyajian berita. Penggunaan stereotype, baik yang bermakna positif maupun negatif, dalam penyajian 
sebuah berita dapat mengundang tuduhan keberpihakan wartawan atau media terhadap seseorang atau kelompok yang ada dalam masyarakat. Stereotype, menurut McQuail merupakan salah satu dimensi yang juga mengukur derajat netralitas pemberitaan. Seharusnya dalam permberitaan, stereotype dapat dihindari karena mengurangi aspek objektivitas berita.

Unsur penting berikutnya adalah juxtaposition dan linkages. Juxtaposition diartikan sebagai menyandingkan dua hal yang berbeda. Juxtaposition digunakan oleh wartawan untuk menyandingkan dua hal yang berbeda seolah-seolah berhubungan dengan maksud untuk menimbulkan efek kontras atau asosiatif, yang pada akhirnya menambah kesan dramatis berita yang disajikan. Dengan demikian, juxtaposition dapat mengubah atau menggeser pemaknaan dua fakta yang sebenarnya berbeda (tidak berhubungan) menjadi sama (berhubungan) secara kontras. Sementara itu, linkages berkaitan dengan upaya wartawan untuk menyandingkan dua fakta yang berlainan dengan maksud untuk menimbulkan efek asosiatif.

Unsur selanjutnya adalah akurasi, akurasi dikaitkan dengan narasumber berita. Narasumber seharusnya memiliki kaitan dengan tema berita, misalnya orang yang mengetahui atau mengalami suatu peristiwa, seorang yang ahli/expert dan bukan karena berafiliasi dengan partai politik atau pendukung capres-cawapres dijadikan narasumber. Kriteria ini penting karena narasumber memegang peran penting dalam memberikan informasi. Keahlian atau pengalaman menyangkut isu atau kejadian membuat penjelasan dan kesaksian yang mereka berikan memiliki nilai akurasi yang tinggi. Dalam pemberitaan, mengukur akurasi juga terkait dengan ketepatan dalam menulis sumber, penggunaan bahasa, penyajian data, penjelasan, keterangan dan sebagainya.

\section{TEMUAN HASIL PENELITIAN}

Dalam pembahasan terkait ideologi media dan pengaruhnya terhadap independensi media pemberitaan di tahun politik 2019 dengan menggunakan objek media massa Kompas TV.

Permasalahan independensi media biasanya merujuk pada berita walau sebenarnya juga berpengaruh pada isi hiburan dan iklan. Namun, penerapan independensi lebih ketat diwujudkan dalam isi berita (Siregar, 2014: 30). Jadwal iklan pasangan capres-cawapres Pilpres 2019 di media massa oleh Komisi Pemilihan Umum (KPU) baru mengizinkan pada 24 Maret 2019 hingga 13 April 2019. Iklan kampanye diatur dalam Peraturan KPU (PKPU) Nomor 23 tahun 2018 tentang Kampanye. Iklan kampanye itu berjalan selama 21 hari hingga satu hari jelang masa tenang yang akan berlangsung selama tiga hari, 13 April hingga 16 April 2019. Saat ini kedua pasangan capres-cawapres tengah memasuki masa kampanye yang dimulai sejak 23 September 2018 hingga 13 April 2019 (Rochmanudin, dalam https://idntimes.com/2018/12/08/newsindonesia/Bisakah-Media-Independen-danNetral-saat-Pemilu-2019?).

Di harian Kompas.com, independensi dipahami dalam konteks keberjarakan dengan berbagai pihak, baik ekonomi maupun politik. Dalam konteks saat ini, independensi adalah menjaga jarak kepada kekuasaan dan partai politik. Untuk menjaga netralitas dan independensi tersebut. Kompas menggunakan tiga mekanisme, yakni melalui rapat redaksi, litbang dan Ombudsmen.

Pemimpin umum telah menggariskan 
Tantangan Ideologi Dan Independensi ...hal 133-145

bahwa Kompas harus tetap independen dengan memberikan ruang kepada semua kelompok untuk menjadikan Kompastempat bertukar gagasan. Rapat redaksi kemudian menerjemahkan hal tersebut. Rapat redaksi menjadi forum tertinggi bagi penentuan dimuat tidaknya sebuah berita, termasuk didalamnya mana yang menjadi headline atau 'sekedar' dimuat dihalaman pertama. Ukuran-ukuran untuk menjadikan suatu berita dimuat ataukah tidak, ditaruh di halaman pertama atau tidak adalah publik atau pembaca dalam pengertian tertentu (Siregar, 2014: 46).

Berikut beberapa pemberitaan Kompas.com selama masa kampanye yang peneliti batasi hanya mengambil dari berbagai sudut pandang pemberitaan, topik kampanye masing-masing pasangan caprescawapres, dari sudut pemerintah/ birokrasi, dan dari lembaga yang berwenang dalam hal ini kepolisian.

\section{Gambar 1}

Kampanye pasangan calon 01

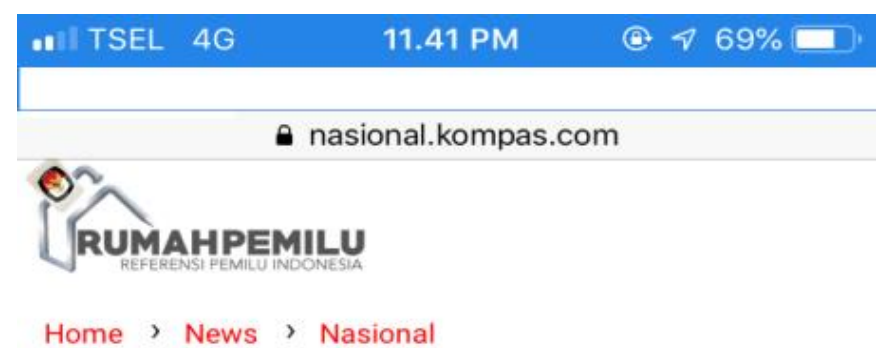

\section{Hal Tentang Kampanye "Putih Bersatu" Jokowi-Ma'ruf di GBK}

Jumat, 12 April 2019 | 09:48 WIB
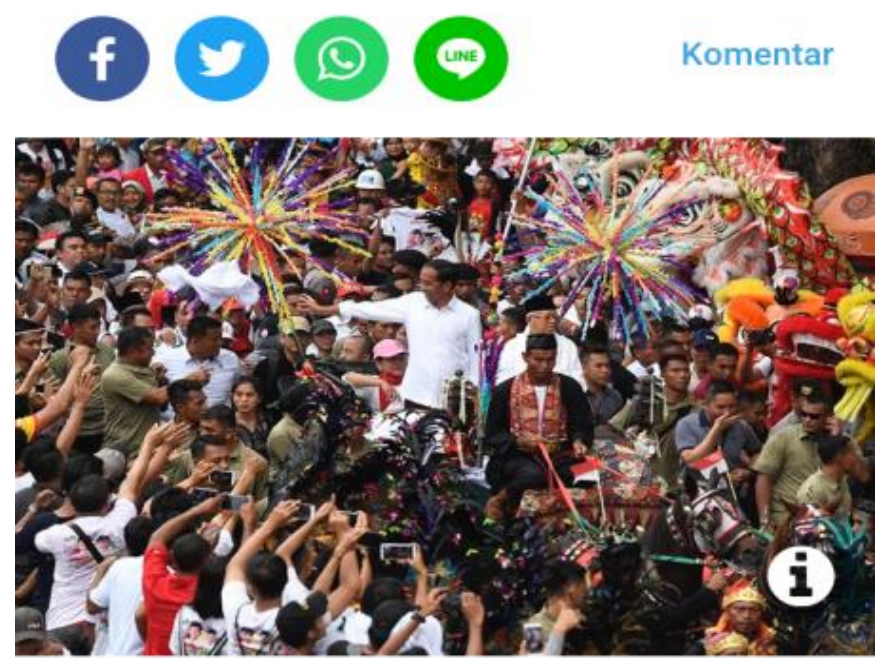

Penulis: Jessi Carina | Editor: Sandro Gatra

Dari judul berita tersebut diatas, jika dipahami menggunakan 7 prinsip independensi; (1) adanya opini, sumber informasi dari sekretaris TKN Jokowi -
Ma'ruf, Hasto kristiyanto. (2) unsur personalisasi; wujudkan keinginan SBY lakukan kampanye inklusif yang dapat mempersatukan berbagai suku, ras dan 
agama. (3) sensasionalisme; tidak kebhinekaan Republik Indonesia. (6) mendramatisir. (4) stereotype; linkage; terdapat 2 perbedaan, yaitu model menyinggung paslon 02 Prabowo kampanye inklusif-eksklusif, dan target mengklaim sejuta massa menghadiri jumlah massa yang datang. (7) akurasi kampanye akbarnya di lokasi yang sama, dalam pemberitaan, informasi yang Geloran Bung Karno. (5) juxtaposition; disampaikan berdasarkan rencana TKN sebutkan perbedaan kampanye inklusif dan dalam persiapan kampanye akbar.

eksklusif yang berhubungan dengan

Gambar 2

Kampanye pasangan calon 02

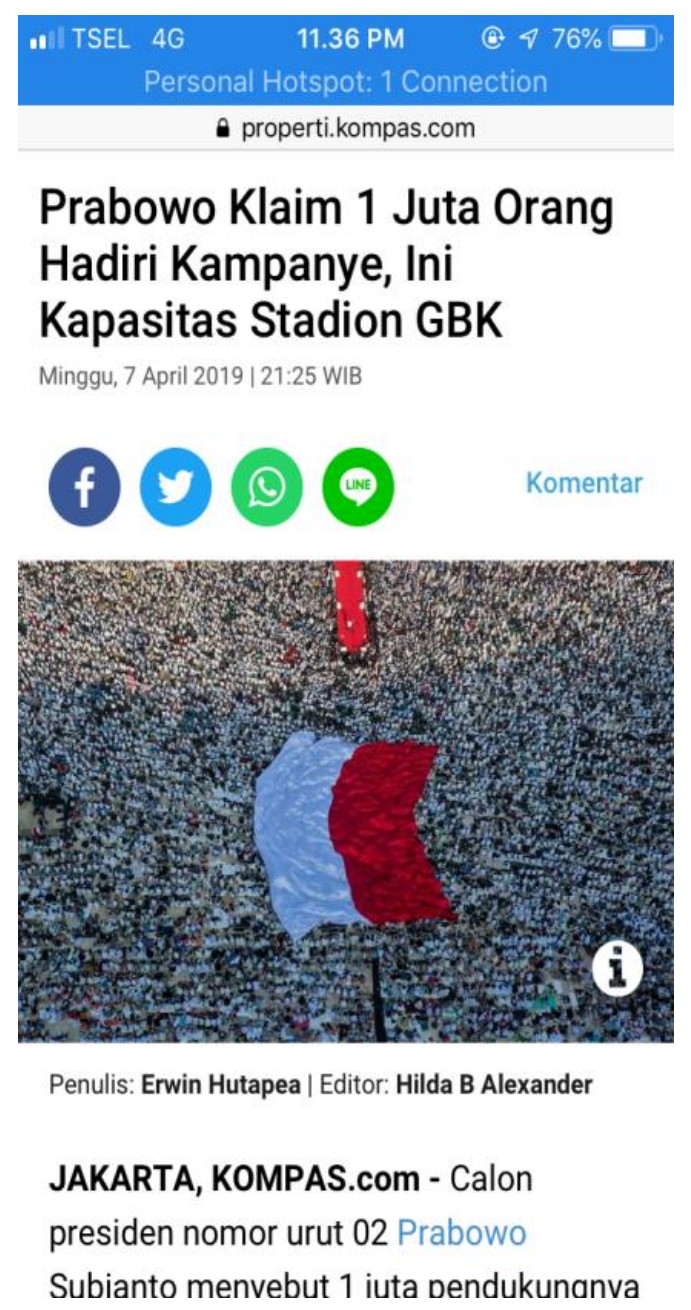

Dari judul berita tersebut diatas, jika datang sesuai dengan yang disampaikan dipahami menggunakan 7 prinsip Prabowo disela-sela pidato kampanyenya. independensi; (1) ada tidaknya opini; dalam berita tidak tertulis teks yang mengandung opini, informasi yang disajikan berdasarkan data secara kuantitatif yang telah dibuktikan kebenarannya. (2) unsur personalisasi; hanya mencamtumkan jumlah masa yang (3) sensasionalisme; penggunaan diksi merupakan kalimat tersurat yang mudah dipahami secara langsung. (4) stereotype; tidak ada unsur keberpihakan, karna wartawan menggunakan narasumber Direktur Utama Pusat Pengelola Komplek 
Tantangan Ideologi Dan Independensi ...hal 133-145

Gelora Bung Karno (PPK GBK). (5) juxtaposition; Prabowo menyebut massa yang hadir sebanyak 1 juta orang, sedangkan hasil wawancara dengan Dirut PPK GBK, jumlah maksimal massa yang hadir adalah sebanyak 461.219 orang. (6) linkage; perbedaan pidato Prabowo dengan Dirut
PPK GBK terkait jumlah massa yang datang merupakan hal yang sama sekali tidak memiliki kesamaan. dan (7) akurasi dalam pemberitaan; berita yang disajikan sesuai data dan fakta lapangan.

\section{Gambar 3}

Pendapat pemerintah tentang kampanye

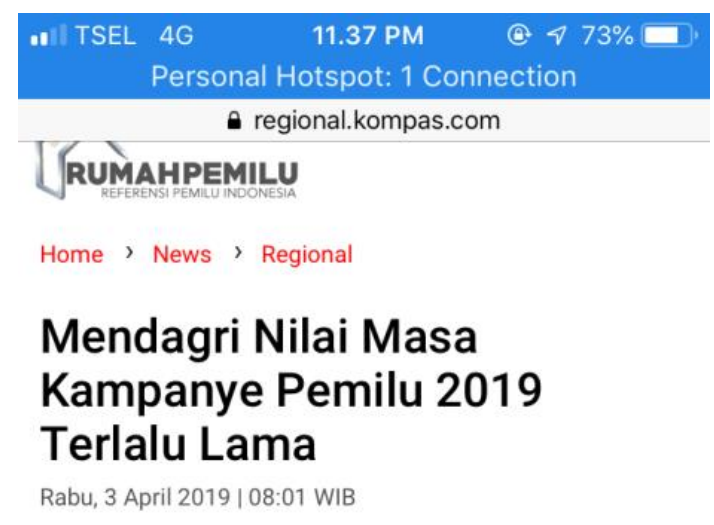

\section{f) (y) (a) Komentar}

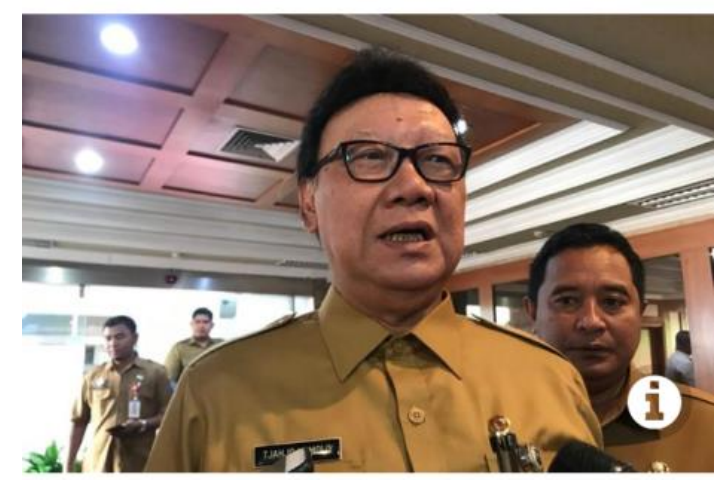

Penulis: Kontributor Surabaya, Ghinan Salman |

Editor: Krisiandi

Dari judul berita tersebut diatas, jika dipahami menggunakan 7 prinsip independensi; (1) ada tidaknya opini; menurut Mendagri, dengan masa kampanye yang relative lama akan berpengaruh negative di masyarakat seperti adanya fitnah, ujaran kebencian, hingga hoaks. (2) unsur personalisasi; menyebut DPR sebagai pemangku kebijakan terkait aturan pemilu. (3) sensasionalisme; diksi yang digunakan dapat dipahami secara langsung. (4) stereotype; tidak mengandung unsur keberpihakan. (5) juxtaposition; penyampaian informasi dari hasil wawancara dengan mendagri menunjukkan adanya perbedaan pendapat dari masa kampanye yang sedang berlaku dengan usulan kampanye mendatang dalam kurun waktu 1 bulan saja yang kemudian dibuktikan bahwa masa kampanye saat ini berjalan lancer sudah mulai cooling down (hingga) masa pencoblosan. (6) linkage, 
perbedaan masa kampanye 2019 dengan 2024 mendatang. dan (7) akurasi dalam pemberitaan; sesuai fakta yang terjadi di lapangan.

Gambar 4

Peringatan kepolisian tentang kampanye

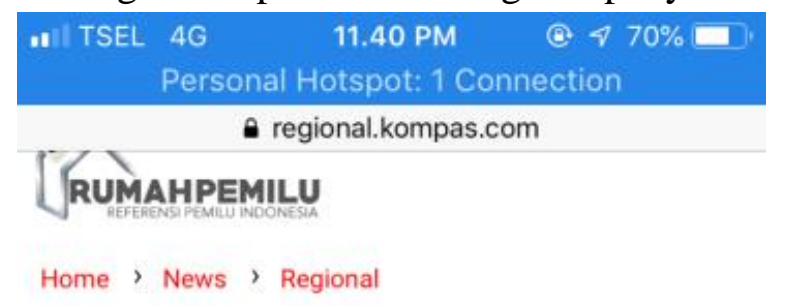

\title{
Kampanye di Masa Tenang Akan Dipenjara Selama 4 Tahun
}

\author{
Senin, 15 April 2019| 13:36 WIB
}
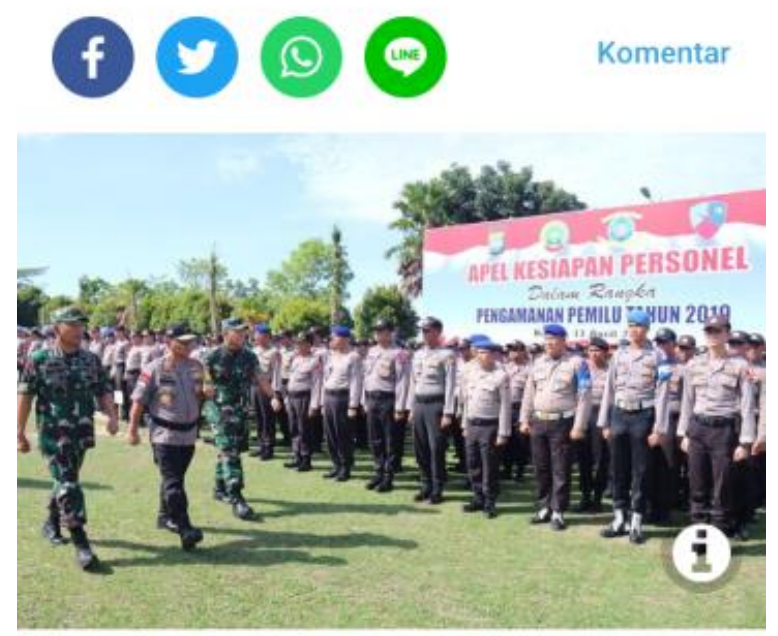

Penulis: Kontributor Batam, Hadi Maulana | Editor:

Farid Assifa

Dari judul berita tersebut diatas, jika dipahami menggunakan 7 prinsip independensi; (1) tidak ada opini, penyampaian informasi tentang sanksi kampanye di masa tenang. (2) unsur personalisasi; disebutkan secara global untuk pilpres dan pileg. (3) sensasionalisme; informasi yang disampaikan sudah mudah dipahami. (4) stereotype; wartawan netral. (5) juxtaposition atau (6) linkage; tidak ada perbedaan yang berhubungan dalam berita yang disampaikan. (7) akurasi dalam pemberitaan; informasi lebih jauh dan detail berdasarkan data terkait larangan melakukan kampanye selama masa tenang berdasarkan UU Nomor 7 tahun 2017 tentang Pemilu, berikut sanksinya dan dalam pasal 276 ayat 2.

Dari keempat berita diatas dapat dilihat bahwa Kompas.com telah berusaha menjaga ideologi media dan independensi pemberitaan media massa di tahun politik 2019 ini dengan menyampaikan berita dari berbagai sudut pandang. 
Tantangan Ideologi Dan Independensi ...hal 133-145

KESIMPULAN DAN SARAN

Ideologi media mengandung pengertian ideologi yang dimiliki oleh media sebagai sebuah institusi atau yang menjadi landasan hidup media. Sedangkan independensi media merupakan sikap yang harus dimiliki sebuah institusi media untuk mempertahankan ideologinya. Media memperlukan sumber daya guna memenuhi kebutuhan dalam memproduksi dan mendistribusikan isinya, sehingga selain berfungsi untuk kepentingan publik, media harus menjalankan fungsi komersial industrinya. Tarik-menarik kepentingan media sebagai institusi masyarakat dan sebagai industri inilah yang menjadi permasalahan ideologi dan independensi media.

Ketidakindependenan berita politik dapat diamati dari sejumlah indikator, yaitu: adanya bias pemberitaan yang cenderung membela kepentingan pemilik, adanya opini mengenai pemilik dan kelompok afiliasinya, mengandung unsur personalisasi, sensasionalisme, stereotype, juxtaposition/ linkage, keberimbangan dan persoalan akurasi. Unsur-unsur tersebut ditunjukkan dengan jelas bagaimana pemberitaan cenderung membela atau menonjolkan kepentingan pemilik dan pemilik dicitrakan positif. Kecenderungan pemberitaan yang mengarah negative pada aktor politik lainnya yang menjadi rival sang pemilik.

Pemberitaan Kompas.com terkait kampanye akbar yang digelar masingmasing paslon capres-cawapres cenderung kurang berimbang, karena pada berita di paslon 01 terdapat stereotype yang menyinggung paslon 02 .

Media yang dianggap independen sekalipun sebenarnya (tidak bisa) dikatakan independen. Media-media mempunyai kecenderungan tertentu dalam memberitakan seorang tokoh politik. Artinya, media akan selalu mengambil posisi tertentu dalam meliput seorang tokoh politik. Suatu media akan memberikan ruang yang lebih besar kepada suatu tokoh politik atau kandidat, dan tidak pada yang lainnya. Oleh karena itu, jauh lebih baik jika media massa harus jujur menyangkut posisinya dan yang seharusnya dilakukan bukan melakukan pelarangan ataupun pembatasan, tapi melaksanakan prinsip fairness dengan sebaik-baiknya.

\section{DAFTAR ISI}

Sumber Buku:

Burton, Graeme. 1999. Media dan Budaya Populer. Yogyakarta: Jalasutra.

Fairclough, Norman. 1992. Discourse and Social Change. Cambridge: Polity Press.

Gramsci, Antonio. 1999. Negara dan Hegemoni. Yogyakarta: Pustaka Pelajar.

Hall, Stuart. 1981. The Whites of Their Eyes: Racist Ideologies and the Media, Los Angeles: Sage.

Jary, David and Julia Jary. 1991. Collins Dictionary of Sociology. Glasgow : Harper Collin.

Jorgensen, Marianne dan Louise Philips. 2002. Discourse Analysis as Theory and Method. Los Angeles: Sage.

Kusumaningrat, Hikmat dan Purnama Kusumaningrat. 2005. Jurnalistik Teori dan Praktik. Bandung: Remaja Rosdakarya.

Lukmantoro, dkk. 2014. Jurnalistik Online: Teori dan Praktik di Era Multimedia. Semarang: AJI Semarang dan Jurusan 
Ilmu Komunikasi Universitas Diponegoro.

McQuail, Denis. 2010. McQuail's Mass Communication Theory. 6 Edition. Amsterdam: Sage Publications.

1992. Media

Performance: Mass Communication and the Public Interest, Sage Publications.

Mulyadi. 2008. Sistem Akuntansi. Jakarta: Salemba Empat.

Rusadi, Udi. 2015. Kajian Media: Isu Ideologis dalam Perspektif, Teori dan Metode. Jakarta: Raja Grafindo Persada.

Sumber Jurnal:

Siregar, Amir Effendi dkk. 2014. "Menakar Independensi dan Netralitas Jurnalisme dan Media di Indonesia". Jurnal Dewan Pers. Edisi No. 09 Juli.

Sumber Lain:

Rochmanudin, Bisakah Media Independen dan Netral saat Pemilu 2019?, diakses pada Selasa 4 Desember 2018, dalam https://idntimes.com/newsindonesia.html 